\title{
RESEÑAS / REVIEWS
}

El PROYECTO ESCULTÓRICO: APROXIMACIONES, ENSAYOS Y EXPERIENCIAS EN EL AULA-TALLER Exposición Centro de Arte La Recova, Santa Cruz de Tenerife (OAC), octubre-noviembre 2018.

Comisarios: Tomás Oropesa, Román Hernández y Francisco J. Viña.

La exposición de proyectos escultóricos recogió una selección de los trabajos desarrollados por los estudiantes de la asignatura Escultura II de 2. ${ }^{\circ}$ curso del Grado en Bellas Artes de la Universidad de La Laguna. Más de un centenar de obras, pertenecientes al período 2005 2018, fueron seleccionadas teniendo en cuenta pautas que consideramos de especial importancia: investigación y estudios previos llevados a cabo, desarrollo conceptual, dominio técnico, calidad expresiva de los materiales utilizados, interés plástico y originalidad.

Tomamos como referencia la maqueta dentro del proyecto escultórico, así como su sentido artístico y comunicativo bajo un enfoque didáctico y pedagógico. En no pocos casos, las maquetas responden a una necesidad, pero con cierta frecuencia dejan de cumplir su papel transitorio dentro del proyecto y se perfilan como «objetos de exposición». Debido a sus características y avanzado nivel de acabado bien pudieran considerarse como obras definitivas, es decir, como auténticas obras escultóricas de pequeño formato.

Nunca pretendimos presentar en la exposición una exhaustiva y profunda reflexión de lo que son leyes y principios básicos del lenguaje escultórico, pero sí aportamos una serie de consideraciones muy claras en torno a los fundamentos de la escultura que nos han guiado a la hora de plantear los ejercicios/problemas a nuestros estudiantes, a saber: a. La escultura, como arte, es una actividad de la mente -que todo lo decide y ordena-, y encuentra su expresión en una configuración significante.

b. La escultura, como arte plástico, se procesa y expresa a través de la materia.

c. La escultura encuentra su estructura significante en la forma tridimensional (relación cuerpo-espacio).

d. La escultura se comprende a partir de múltiples puntos de vista, que pueden ser percibidos e interpretados aisladamente, pero sólo la confluencia mental de estos aspectos parciales permitirá la comprensión de su sentido último y global.

e. En la percepción escultórica intervienen, de forma determinante, los sentidos visual y háptico.

f. La configuración escultórica viene mediatizada por el nivel tecnológico y los códigos propios de la cultura en la que se ve inmerso el escultor, además de su particular concepción del mundo y sensibilidad.

Bajo estas premisas abordamos una serie de temas en torno a conceptos fundamentales de la escultura:

- El espacio como elemento estructural del volumen.

- El volumen-masa: el espacio ocupado.

- La composición variable: un juego con el objeto y el espacio.

- La escultura construida y habitada.

- De la escultura sustentada a la ausencia de la peana.

- Escultura y movimiento. El movimiento real o inducido.

- Moldes para multiplicar. 
La motivación de los estudiantes ha jugado un papel decisivo en todo el proceso de enseñanza-aprendizaje y se ha reflejado en los "modos de hacer", tanto en su trabajo individual como en el colectivo. Siempre mostraron un compromiso con su propio trabajo sugiriendo no sólo propuestas complejas de configuración, sino también aportando múltiples y variadas soluciones a los problemas planteados por los profesores.

Román Hernández GonzÁlez Universidad de La Laguna romher@ull.edu.es DOI: https://doi.org/10.25145/j.bartes.2019-20.14.08

\section{IMÁGENES}
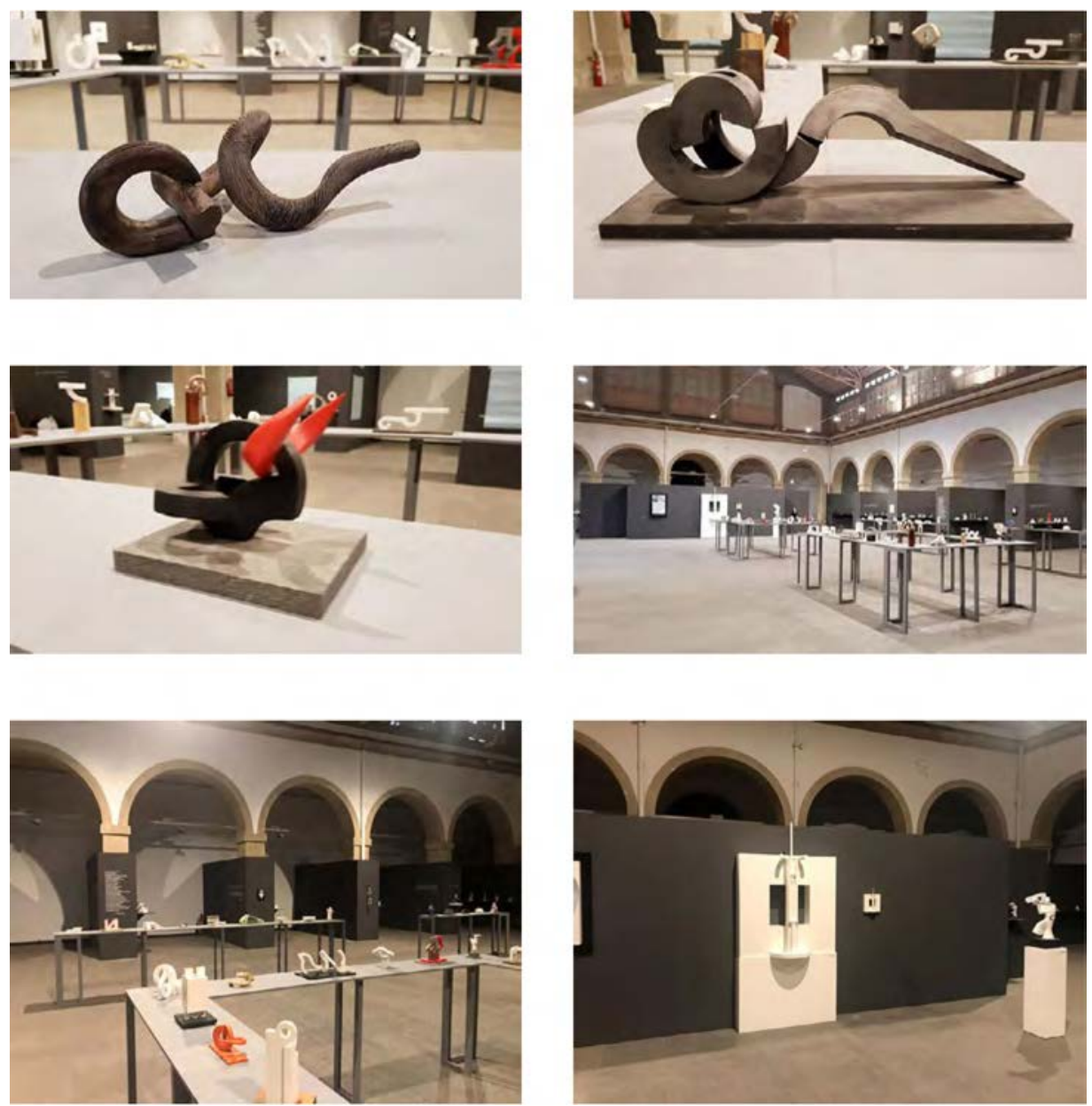